\title{
FORMULATION AND EVALUATION OF PANTOPRAZOLE FLOATING TABLETS
}

\author{
Prasanna Reddy* ', Dr. Manichandrika, K. Madhurima, Nimra Fatima, Arjuma Aliya, Kulsum \\ Siddiqui, Nikhath Begum. \\ Bojjam Narasimhulu Pharmacy College For Women, Vinaynagar, Saidabad. Hyderabad-500059.
}

ABSTRACT : Oral route of administration gets the highest priority for the delivery of drug as well as better patient compliance. Floating tablet is selected for achieving a prolonged and predictable drug delivery profile in the gastrointestinal tract to control the gastric residence time using a gastro retentive dosage forms that will provide as with new and important therapeutic options. The design of oral controlled drug delivery systems is aimed primarily to achieve more predictable and increased bioavailability. However, this system have several physiological difficulties, such as inability to restrain and localized oral control drug delivery systems within desired reasons of the gastro intestinal tract and the highly variable nature of the gastric emptying process. Gastric emptying time in humans, which is normally 2-3 hours through the main absorption area (stomach or upper part of intestine), can result in incomplete drug release from oral controlled drug delivery system leading to diminished efficacy of an administered dose. Intimate contact of oral controlled drug delivery system with the absorbing membrane has the potential to maximize drug absorption and also influence the rate of drug absorption.These consideration have lead to the development of oral controlled gastroretentive dosage forms possessing gastric retention capabilities Pantoprazole floating tablets is used to treat and prevent bacterial infections in the stomach and intestines.

Keywords: Bioadhesive Floating Matrix, Pantoprazole, Polymers, sodium bi carbonate and citric acid, in vitro drug release studies.

\section{I.INTRODUCTION}

Gastroretentive drug delivery systems are designed to be retained in the stomach for a prolonged time and release their active ingredients and thereby enable sustained and prolonged input of the drug to the upper part of the gastrointestinal tract. ${ }^{1,2}$ A modified release drug delivery system with prolonged residence time in the stomach is of particular interest for drugs- acting locally in the stomach; having an absorption window in the stomach or in the upper part of small intestine; those unstable in the intestinal or colonic environments; or those having low solubility at high $\mathrm{pH}$ values. ${ }^{3}$ Floating drug delivery systems have a bulk density less than gastric fluids and so remain buoyant in the stomach without affecting the gastric emptying rate for a prolonged period of time. ${ }^{4}$ While the system is floating on the gastric contents, the drug is released slowly at the desired rate from the system. After release of drug, the residual system is emptied from the stomach. This results in an increased gastric retention time and control of the fluctuation in plasma drug concentration. Pantoprazole is protein pump inhibitor (PPI) used for the treatment of acute duodenal ulcer, acute benign gastric ulcer, gastroesophageal reflux disease (GERD) and prophylactic use in duodenal ulcer. ${ }^{5,6}$ It acts by competitive inhibition of $\mathrm{H}+\mathrm{K}+$ ATPase enzyme of the gastric parietal cells resulting in reduced gastric acid secretion i.e. having local action in the stomach. The recommended oral dosage is generally $45 \mathrm{mg}$ for acute duodenal ulcer, acute benign gastric ulcer and gastro esophageal reflux (GERD) and is prescribed for the duration of 8-12 weeks. The drug has a short biological half life (1-2 h) and local action in stomach which makes it suitable candidate for FDDS. ${ }^{7}$

\section{MATERIAL AND METHODS}

MATERIAL

Pantoprazole was collected as a gift sample from aurbindho, Hyderabad and various excipients like HPMC, Sodium alginate were purchased from AR chemicals, Hyderabed. 


\section{METHODODOLOGY ${ }^{8,9,10}$}

\section{Formulation development}

Table-1: Composition of Pantoprazole floating tablets

\begin{tabular}{|c|c|c|c|c|}
\hline \multirow{2}{*}{ Ingredients } & \multicolumn{4}{|c|}{ Formulations } \\
\cline { 2 - 5 } & F1 & F2 & F3 & F4 \\
\hline Pantoprazole & 100 & 100 & 100 & 100 \\
\hline HPMC K100M (mg) & 100 & - & 50 & 25 \\
\hline Sodium alginate (mg) & - & 100 & 50 & 75 \\
\hline MCC & 170 & 170 & 170 & 170 \\
\hline Sodium bi carbonate (mg) & 25 & 25 & 25 & 25 \\
\hline Magnesium stearate (mg) & 3 & 3 & 3 & 3 \\
\hline Talc (mg) & 2 & 2 & 2 & 2 \\
\hline Total wt (mg) & 400 & 400 & 400 & 400 \\
\hline
\end{tabular}

\section{Procedure for Formulation}

\section{Preparation of Formulation:}

1. Drug and polymers pass through 40 \# mesh separately and then transfer it to poly bag and mix it for 3 minutes.

2. Add diluents and other excipients to the above mixture. Finally add the Glidant (Magnesium Stearate) and Lubricant (Talc) to the above blend mix it for $2 \mathrm{~min}$.

3. Compressed the above lubricated blend by using $10 \mathrm{~mm}$ round punches.

\section{Evaluation of tablets ${ }^{11,12}$}

The quantitative evaluation and assessment of a tablets chemical, physical and bioavailability properties are important in the design of tablets and to monitor product quality. There are various standards that have been set in the various pharmacopoeias regarding the quality of pharmaceutical tablets. These include the diameter, size, shape, thickness, weight, hardness, Friability, Buoyancy test and in vitro-dissolution characters.

\section{Physical Appearance}

The general appearance of a tablet, its identity and general elegance is essential for consumer acceptance, for control of lot-to-lot uniformity and tablet-to-tablet uniformity. The control of general appearance involves the measurement of size, shape, colour, presence or absence of odour, taste etc.

\section{Size \& Shape}

It can be dimensionally described \& controlled. The thickness of a tablet is only variables. Tablet thickness can be measured by micro-meter or by other device. Tablet thickness should be controlled within a $\pm 5 \%$ variation of 
standard value.

\section{Weight variation test}

Twenty tablets were weighed individually and the average weight was calculated.The individual tablet weights are then compared to the average weight. Not more than two tablets should differ in their average weight by more than percentages stated in USP. No tablet must differ by more than double the relevant percentage.

\section{Content Uniformity}

Randomly select 30 tablets. 10 of these assayed individually. The Tablet pass the test if 9 of the 10 tablets must contain not less than $85 \%$ and not more than $115 \%$ of the labeled drug content and the 10th tablet may not contain less than $75 \%$ and more than $125 \%$ of the labeled content. If these conditions are not met, remaining 20 tablets assayed individually and none may fall outside of the 85 to $115 \%$ range.

\section{Friability}

A number of tablets are weighed and placed in the apparatus where they are exposed to rolling and repeated shocks as they fall 6 inches in each turn within the apparatus. After four minutes of this treatment or 100 revolutions, the tablets are weighed and the weight compared with the initial weight. The loss due to abrasion is a measure of the tablet friability. The value is expressed as a percentage. A maximum weight loss of not more than $1 \%$ of the weight of the tablets being tested during the friability test is considered generally acceptable and any broken or smashed tablets are not picked.

The percentage friability was determined by the formula:

$$
\% \text { friability }=\left(\mathrm{W}_{1}-\mathrm{W}_{2}\right) / \mathrm{W}_{1} \mathrm{X} 100
$$

$\mathrm{W}_{1}=$ Weight of tablets before test

$\mathrm{W}_{2}=$ Weight of tablets after test

\section{Floating lag time}

The time between the introduction of the tablet into the medium and its rise to upper one third of the dissolution vesselis termed as floating lag time and the time for which the dosage form floats is termed as th e floating or flotation time. These tests are usually performed in simulated gastric fluid or $0.1 \mathrm{NHCl}$ maintained at

$37{ }^{\circ} \mathrm{C}$, by using USP dissolution apparatus containing $900 \mathrm{ml}$ of $0.1 \mathrm{~N} \mathrm{HCl}$ as the dissolution medium.

\section{Drug release}

The drug release from the Pantoprazole tablets was investigated in a USP-I (basket) apparatus, $900 \mathrm{ml}$ of $0.1 \mathrm{~N}$ $\mathrm{HCl}\left(50 \mathrm{rpm}, 37^{\circ} \mathrm{C}\right)$. At predetermined time intervals, 5-ml samples were withdrawn and take $1 \mathrm{ml}$ sample and diluted to $10 \mathrm{ml}$ and then analyzed with UV spectrophotometry at $\lambda \max 326 \mathrm{~nm}$.

\section{Stability studies}

The success of an effective formulation can be evaluated only through stability studies. The purpose of stability testing is to obtain a stable product which assures its safety and efficacy up to the end of shelf life at defined storage conditions and peak profile. The prepared Pantoprazole floating tablets were placed on plastic tubes containing desiccant and stored at ambient conditions, such as at room temperature, $40 \pm 2^{\circ} \mathrm{c}$ and refrigerator $2-8^{\circ} \mathrm{c}$ for a period of 30 days.

\section{RESULTS AND DISCUSSION}

\section{Evaluation of Pre compression parameters}

Table-2: Evaluation parameters of Pantoprazole pre compression parameters

\begin{tabular}{|l|l|l|c|l|c|}
\hline $\begin{array}{l}S . \\
n \\
o\end{array}$ & $\begin{array}{l}\text { Bulk } \\
\text { density }\end{array}$ & $\begin{array}{l}\text { Tapped } \\
\text { density }\end{array}$ & Compressibility index & $\begin{array}{l}\text { Hausner } \\
\text { ratio }\end{array}$ & $\begin{array}{l}\text { Angle of } \\
\text { repose(0) }\end{array}$ \\
\hline F1 & 0.442 & 0.539 & 17.99 & 1.21 & $29^{0}$ \\
\hline F2 & 0.451 & 0.563 & 19.89 & 1.24 & $31^{0}$ \\
\hline F3 & 0.440 & 0.553 & 20.43 & 1.25 & $27^{0}$ \\
\hline F4 & 0.452 & 0.561 & 19.42 & 1.24 & $30^{0}$ \\
\hline
\end{tabular}




\section{Evaluation of the Prepared Tablets for Physical Parameters}

All formulations were tested for Physical parameters like Hardness, thickness, Weight Variation, Friability and found to be within the Pharmacopoeial limits. The results of the tests were tabulated. The drug content of all the formulations was determined and was found to be within the permissible limit. This study indicated that all the prepared formulations were good.

Table-3: Evaluation parameters of Pantoprazole floating tablets

\begin{tabular}{|c|c|c|c|c|}
\hline Parameter & F1 & F2 & F3 & F4 \\
\hline $\begin{array}{c}\text { Weight } \\
\text { variation }\end{array}$ & 400 & 399 & 398 & 400 \\
\hline $\begin{array}{c}\text { Thickness } \\
\text { (mm) }\end{array}$ & 3.3 & 3.1 & 3.3 & 3.2 \\
\hline $\begin{array}{c}\text { Hardness } \\
\text { (kg/cm } \mathbf{2}^{\text {(m) }}\end{array}$ & 5.1 & 5.2 & 5.1 & 5.4 \\
\hline Friability & 0.65 & 0.62 & 0.69 & 0.61 \\
\hline $\begin{array}{c}\text { Content } \\
\text { uniformity }\end{array}$ & 97.20 & 95.26 & 92.40 & 96.36 \\
\hline $\begin{array}{c}\text { Floating lag } \\
\text { time } \\
\text { (Sec) }\end{array}$ & 60 & 49 & 47 & 50 \\
\hline
\end{tabular}

\section{Floating lag time}

The floating tablets of Pantoprazole were prepared by using direct compression technique. Eight different formulations were prepared using different ratios of polymers. The prepared formulations were evaluated for floating lag time and buoyancy time. Sodium bicarbonate induced carbon dioxide generation in presence of dissolution medium $(0.1 \mathrm{~N} \mathrm{HCl})$. It was observed that the gas generated is trapped and protected within the matrix, formed by polymers, thus density of the tablet decreased and it becomes buoyant. The floating lag time of the optimized formulation F1 was $60 \mathrm{sec}$.
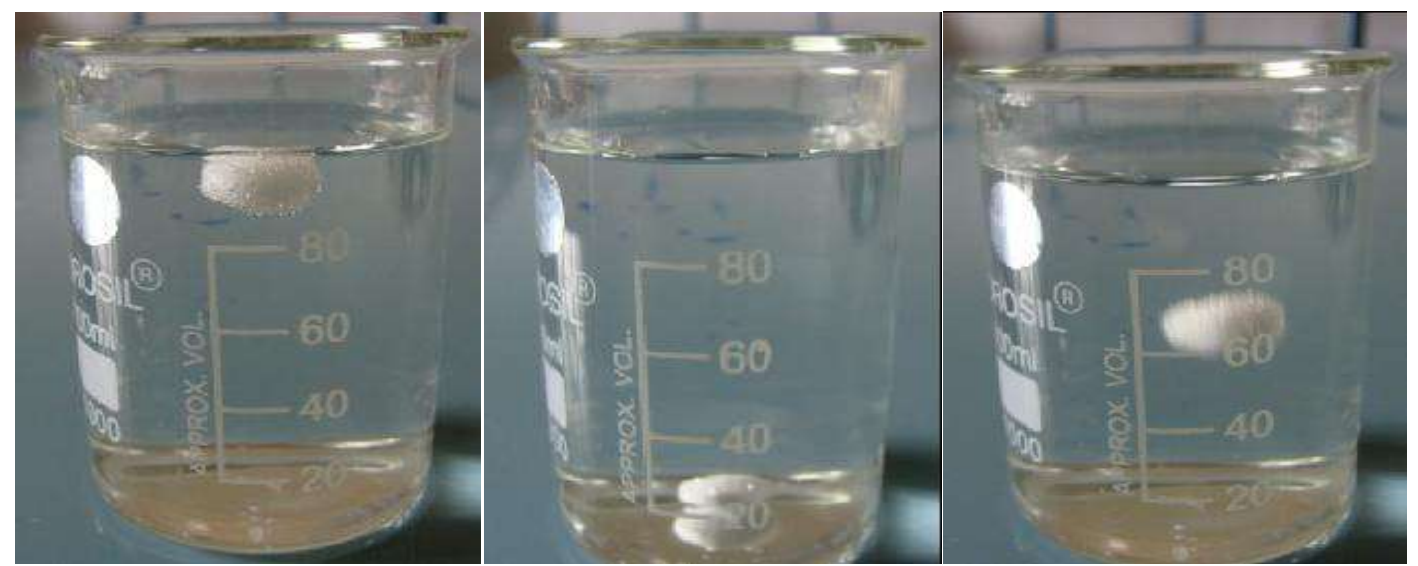

In vitro Dissolution studies

Fig-1: Floating of the tablets

The samples were withdrawn at predetermined time points, and were analyzed spectrophotometrically at $396 \mathrm{~nm}$. 
Table-4: In vitro drug release of Pantoprazole floating tablets

\begin{tabular}{|c|c|c|c|c|}
\hline \multicolumn{5}{|c|}{ \%Drug Release } \\
\hline Time & F1 & F2 & F3 & F4 \\
\hline 0 & 0 & 0 & 0 & 0 \\
\hline 1 & 17.25 & 16.21 & 16.65 & 15.62 \\
\hline 2 & 28.94 & 26.18 & 25.85 & 25.68 \\
\hline 3 & 36.15 & 35.12 & 31.25 & 30.91 \\
\hline 4 & 48.25 & 47.14 & 44.92 & 42.95 \\
\hline 5 & 56.12 & 54.92 & 52.54 & 50.20 \\
\hline 6 & 69.85 & 64.83 & 61.15 & 61.82 \\
\hline 7 & 78.26 & 71.24 & 75.36 & 76.25 \\
\hline 8 & 93.28 & 89.32 & 90.31 & 89.55 \\
\hline
\end{tabular}

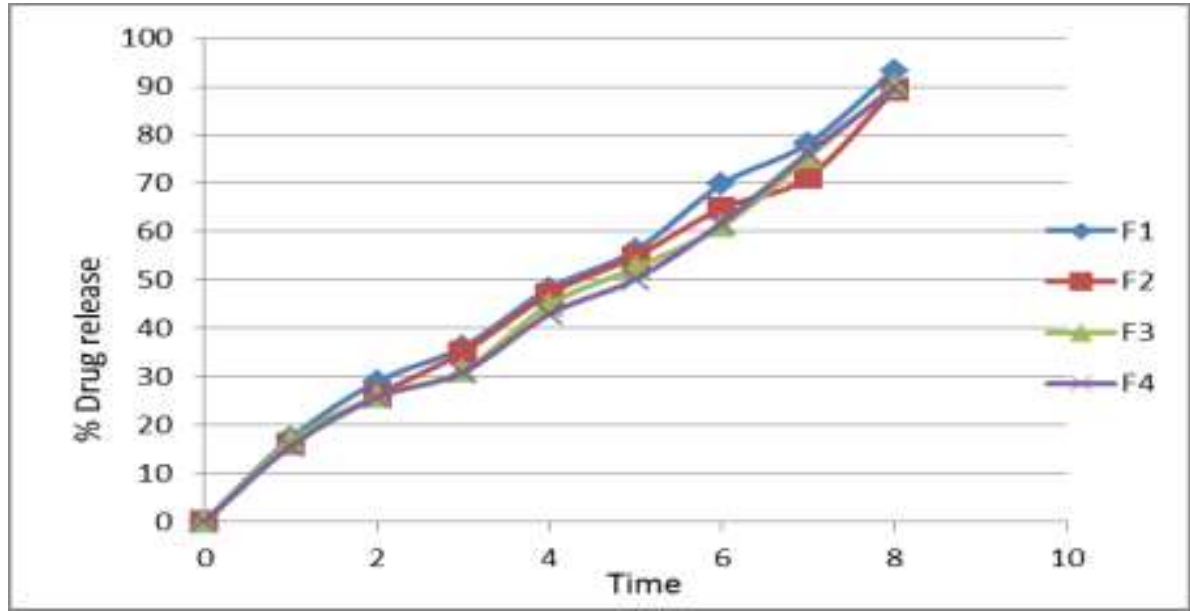

Fig-2: In vitro drug release for all the formulations

Stability Study

There was no significant change in physical and chemical properties of the tablets of formulation F-1 after 30 days. Parameters quantified at various time intervals were shown.

Table-5: Stability study for optimized formulation

\begin{tabular}{|c|c|c|c|c|}
\hline $\begin{array}{c}\text { Formulation } \\
\text { Code }\end{array}$ & Parameters & Initial & $\begin{array}{c}1^{\text {st }} \\
\text { Month }\end{array}$ & $\begin{array}{c}\text { Limits as per } \\
\text { Specifications }\end{array}$ \\
\hline F-1 & $\begin{array}{c}25^{0} \text { C/60\% RH } \\
\% \text { Release }\end{array}$ & 93.28 & 93.14 & $\begin{array}{c}\text { Not less than } \\
85 \%\end{array}$ \\
\hline F-1 & $\begin{array}{c}30^{0} \text { C/75\% RH } \\
\% \text { Release }\end{array}$ & 93.28 & 93.20 & $\begin{array}{c}\text { Not less than } \\
85 \%\end{array}$ \\
\hline F-1 & $\begin{array}{c}40^{0} \mathrm{C} / 75 \% \text { RH } \\
\% \text { Release }\end{array}$ & 93.28 & 93.16 & $\begin{array}{c}\text { Not less than } \\
85 \%\end{array}$ \\
\hline
\end{tabular}




\section{CONCLUSION}

The objective of the present study is to develop a Floating tablets of Pantoprazole. In this present study an attempt was made to increase the GI residence time of Pantoprazole, as the drug is having less gastric residence time, by formulating in to Floating tablets. Systematic studies were conducted using different concentration of rate releasing different polymers for extending the drug release in upper GIT. All the prepared systems were evaluated for the different properties. Before the preparation of tablets, preformulation studies to find out the micromeritic properties to assess flowability, compressibility properties and solubility studies and all the formulations gave good results for above preformulation studies. Formulated tablets gave satisfactory results for various physical tablet evaluation parameters like tablet dimensions, hardness, friability, weight variation, buoyancy, content uniformity, all the formulations were found within the permissible range. Finally it was concluded that: Among all the formulations (F1-F4), it was observed that formulation-1 has shown better buoyancy and dissolution profile. So Formulation-1 was found to be the best formulation among others.

\section{REFERENCE}

1. Bagherwal A, Patidar DK, Sharma P. Formulation and evaluation of floating tablets of ciprofloxacin hydrochloride. Int J Comp Pharma 2010;1:1-4.

2. Kumar R. Development and in-vitro evaluation of sustained release floating matrix tablets of metformin hydrochloride. Int J Pharm Sci Res 2010;1:96-101.

3. Chodavarapu NP, Yendluri RB, Suryadevara H, Reddy P, Chhatoi P. Formulation and evaluation of abelmoschusesculentus mucilage based metformin hydrochloride floating matrix tablets. Int $\mathrm{J}$ Pharm Tech 2011;3:2725-45.

4. Kshirsagar RV, Jain V, Wattamwar S. Effect of different viscocity grade HPMC polymer on gastroretantive drug delivery of metformin hydrochloride. Int J Appl Pharm 2009; 1:44-50.

5. Chandiran IS, Kumar BP, Narayan V. Formulation and in-vitro evaluation of floating drug delivery system for salbutamol sulphate. Int J Pharm Biomed Sci 2010; 1(1):12-15.

6. Hu L, Li L, Yang X, Liu W, Yang J, Jia Y, et al., Floating matrix dosage form for dextromethorphan hydrobromide based on gas forming technique. In-vitro and in-vivoevalvation healthy volunteers. Eur J Pharm Sci 2011;42:99-105.

7. Raju BD, Sreenivas R, Varma MM. Formulation and evaluation of floating drug delivery system of metformin hydrochloride. J Chem Pharm Res 2010;2(2):274-78.

8. Senthilkumar SK, Jaykar B, Kavimani S. Formulation and evaluation of gastroretentive floating drug delivery system of rabeprazole sodium. Int J Biopharm 2011;2(2):57-62.

9. Mohammed MS. Formulation and in-vitro evaluation of sustained release intragastric tablets of propranolol hydrochloride using natural polymer. J Pharm Biomed Sci 2011;10(10):1-10.

10. Goole J, Vanderbist F, Amighi K. Development and evaluation of new multi-unit levodopa sustained-release floating dosage forms. Ind J Pharm 2007;334:35-41.

11. Sauzet C, Bruno CM, Nicolas M, Kister J, Piccerdle P, Prinderre P. An innovative floating gastro retentive dosage system. Formulation and in-vitro evaluation. Int J Pharm 2009;378:23-29.

12. Agrawal, A.M., Manek, R.V., Kolling, W.M., Neau, S.H., 2003. Studies on the interaction of water with ethylcellulose: effect of polymer particle size. AAPS Pharm. Sci. Tech. 4, E60.

13. Atyabi, F., Sharma, H.L., Mohammad, H.A.H., Fell, J.T., 1996a. Controlled drug release from coated floating ion exchange resin beads. J. Control. Rel. 42, 25-28.

14. Babu, V.B., Khar, R.K., 1990. In vitro and in vivo studies of sustained-release floating dosage forms containing salbutamol sulfate. Pharmazie 45, 268-270.

15. Badve, S.S., Sher, P., Korde, A., Pawar, A.P., 2007. Development of hollow/porous calcium pectinate beads for floating-pulsatile drug delivery. Eur. J. Pharm. Biopharm. 65, 85-93. 